\title{
PENGARUH REWARD, PUNISHMENTDAN KEADILAN ORGANISASI TERHADAP KINERJA KARYAWAN PT MAWAR SEBELAS SERANG
}

\author{
Suryaman \\ Fernando Hasudungan Fernando \\ Unserasuryaman15@gmail.com \\ Universitas Serang Raya
}

\begin{abstract}
ABSTRAK
Penelitian ini bertujuan untuk mengetahui reward, punishmentdan keadilan organisasi terhadap kinerja karyawan PT Mawar Sebelas Serang.

Metode yang digunakan adalah kuantitatif bersifat deskriptif dan asosiatif. Penelitian dilakukan di PTMawar Sebelas pada tanggal 8 Januari 2019 s/d Juni 2019. Populasi penelitian sebanyak 55 karyawandengan menggunakan sampling jenuh. Data dikumpulkan dengan menggunakan instrumen penelitian dan diolah menggunakan SPSS statistic versi 24.0windows.Proses reward, punishment dan keadilan organisasi menempati peran yang pentinguntuk merealisasikan tujuan perusahaan yang optimal yangmemerlukan sumber daya manusia yang berkualitas, namun pada kenyataannya berdasarkan observasi awal pada PTMawar Sebelas,kinerja perusahaan kurang baik, karena nilai ratarata skor sebesar 33,6 dibawah skor 35, akibat rendahnya keterampilan dalam bekerjadan dari pengetahuan pekerjaan masih rendah.

Berdasarkan hasil penelitian dapat disimpulkan bahwa: Terdapat pengaruh positif dan signifikan antara reward,punishmentdan keadilan organisasi baik secara parsial maupun simultan dengan kontribusi 35,5\% terhadap kinerja karyawan,sedangkan sisanya 74,5\% dipengaruhi oleh faktor lain yang tidak diteliti.

Hasil penelitian ini merekomendasikan bahwa kinerja karyawan dapat ditingkatkan melalui variabel yang mendominasi yaitu variabel rewardsebesar 0,465untuk punishmentsebesar 0,402 sedangkan keadilan organisasi sebesar 0,390. Dalam hal ini untuk meningkatkan kinerja karyawan perlu peningkatan, kemampuan, keterampilan dalam menyelesaikan tugas pada PT Mawar Sebelas Serang.
\end{abstract}

Kata kunci : Reward, Punishment dan Keadilan Organisasi terhadap Kinerja Karyawan.

\section{ABSTRACT}

This study aims to determine the reward, punishment and organizational justice for the performance of employees of PT MawarSebelasSerang. The method used is quantitative descriptive and associative. This research was conducted at PT MawarSebelas on January 8, 2019 to June 2019. The study population was 55 employees using saturated sampling. Data were collected using research instruments and processed using SPSS statistics version 24.0 windows.

The process of reward, punishment and organizational justice plays an important role in realizing optimal company goals that require quality human resources, but in fact based on preliminary observations at PT MawarSebelasDrangong, the company's performance is not good, because the average score is 33. , 6 below the score of 35, due to low skills in work and from low job

knowledge.Based on the research results it can be concluded that: There is a positive and significant influence between reward, punishment and organizational justice either partially or

simultaneously with a contribution of $35.5 \%$ to employee performance, while the remaining $74.5 \%$ is influenced by other factors not examined.The results of this study recommend that employee performance can be improved through the dominating variable, namely reward variable of 0.465 for punishment of 0.402 while organizational justice is 0.390. In this case to improve employee performance, it is necessary to improve, ability, skills in completing tasks at PT MawarSebelasSerang.

Keywords :Reward, Punishment and Organizational Justice on Employee Performance 


\section{PENDAHULUAN}

Perusahaan dituntut untuk efektif dalam pengelolaan, karena bila tidak maksimal tidak dapat bersaing dengan perusahaan lain. Untuk menghadapi tantangan tersebut maka aset perusahaan yang paling berharga adalah sumber daya manusianya. Bukan saja untuk tujuan perkembangan ekonomi, tetapi untuk segala aspek perkembangan kehidupan.

Untuk menciptakan kinerja yang tinggi dibutuhkan adanya peningkatan kerja yang optimal dan mampu mendayagunakan potensi sumber daya manusia yang dimiliki guna menciptakan tujuan organisasitergantung pada keefektifitasan pengelolaan sumber daya manusia. Seiring dengan perubahan lingkungan organisasi yang semakin kompleks dan kompetitif.

\section{TUJUAN PENELITIAN}

Tujuan penelitian untuk menganalisis :

1. Pengaruh reward terhadap kinerja karyawan pada PT Mawar Sebelas

2. Pengaruh punishment terhadap kinerja karyawan pada PT Mawar Sebelas

3. Pengaruh keadilan organisasi terhadap kinerja karyawan pada PT Mawar Sebelas

4. Pengaruh reward, punishment dan keadilan organisasi terhadap kinerja karyawan pada PT Mawar Sebelas

\section{LANDASAN TEORI}

\subsection{Reward}

Reward merupakan perangsang atau motivasi untuk meningkatkan kinerja yang dicapai seseorang yang pada umumnya diwujudkan dalm bentuk financial (insentif moneter) seperti pemberian insentif, tunjangan, bonus dan komisi ( Riva'i, 2004: 269).reward Menurut Ivanceviche ( 2007: 226-227 ), bahwa reward dapat diklasifikasikan kedalam dua kategori utama, yaitu sebagai berikut:

\section{RewardIntrinsik}

a. Penyelesaian ( completion )

Beberapa orang memiliki kebutuhan untuk menyelesaikan tugas atau pekerjaannya, dan mereka akan merasa puas setelah tugas atau pekerjaan tersebut terselesaikan dengan baik.

b. Pencapaian ( achievement)

Terkadang seseorang akan merasa bangga terhadap dirinya sendiri setelah meraih sebuah tujuan yang menantang

c. Otonomi ( autonomy)

Diberinya kesempatan untuk mengambil sebuah keputusan penting dalam organisasi.

d. Pertumbuhan Pribadi ( personal growth)

Dengan berbagai macam jenis tugas yang diberikan oleh seseorang karyawan tentu saja akan meningkatkan keterampilan yang dimilikinya.

2. Reward Ekstrinsik adalah sebuah penghargaan yang diberikan oleh seseorang yang memiliki jabatan lebih tinggi atas pencapaiannya yang telah seseorang capai. Bentuk penghargaan langsung yaitu berupagaji, upah, tunjangan dan bonus sedangkan penghargaan tidak langsung yaitu berupa pesangon, jaminan sosial dan asuransi.

\subsection{Punishment}

Menurut Ivancevich et.al ( 2007: 224) punishment adalah sesuatu konsekuensi yang tidak menyenangkan atau tidak diinginkan yang diberikan oleh atasan atas suatu perilaku tertentu yang telah dilakukan.Menurut Purwanto ( 2006: 189 ) secara garis besar punishment dapat dibedakan menjadi dua macam yaitu:

1. Punishment Preventif
a. Tata tertib
b. Anjuran dan perintah
c. Larangan
d. Pengawasan
e. Paksaan
f. Disiplin

2. Punishment Represif

a. Pemberitahuan 
b. Teguran dan Peringatan

c. Hukuman

\subsection{Keadilan Organisasi}

Gibson dkk ( Dewi Nurcahyani 2016 ), Mendefinisikan keadilan organisasi sebagai suatu tingkat dimana seorang individu merasa diperlukan sama diorganisasi tempat dia bekerja sedangkan menurut Niehoff dan Moorman ( 1993:537 ) terdapat indikator dalam keadilan organisasional yang digunakan dalam penelitian ini, yaitu :

1. Keadilan Distributif
a. Jadwal Kerja
b. Tingkat Gaji
c. Beban Kerja
d. Penghargaan yang didapatkan

2. Keadilan Prosedural

a. Mempertimbangkan keputusan pekerja

b. Kekhawatiran karyawan didengar oleh pimpinan

c. Mekanisme pengumpulan informasi yang akurat dan objektif

d. Mengklarifikasi keputusan dan memberikan tambahan informasi

e. Penetapan keputusan yang konsisten

3 Keadilan Interaksional

a. Memperlakukan karyawan dengan baik dan perhatian

b. Memperlakukan karyawan dengan terhormat dan bermartabat

c. Peka terhadap kebutuhan karyawan dengan cara yang tepat

d. Peduli terhadap hak-hak karyawan

\subsection{Kinerja}

Kinerja menurut Hasibuan ( 2002:84 ) adalah suatu hasil kerja yang dicapai seseorang dalam melaksanakan tugas-tugasnya atas kecakapan, usaha dan kesempatan sedangkan teori yang digunakan sebagai alat ukur variable kinerja karyawan menggunakan teori Anwar Prabu Mangkunegara ( 2013:67 ) dengan dimensi:
1) Kuntitas
2) Kualitas
3) Kemampuan
4) Ketepatan Waktu

\section{HIPOTESIS PENELITIAN}

1. H-1 :Diduga rewardberpengaruh positif dan signifikan terhadap kinerja karyawan

2. H-2 : Diduga punishmentberpengaruh positif dan signifikan terhadap kinerja karyawan

3. H-3 : Diduga keadilan organisasiberpengaruh positif dan signifikan terhadap kinerja karyawan

4. H-4 : Diduga reward, punishment dan keadilan organisasiberpengaruh positif dan signifikan terhadap kinerja karyawan

\section{METODE PENELITIAN}

Metode penelitian ini menggunakan kualitatif bersifat deskriptif dan asosiatif dengan menggunakan lima tahap yaitu, pertama tahap konseptual dipokuskan pada upaya untuk merumuskan dan membatasi masalah, meninjau kepustakaan yang relevan, mendefinisikan kerangka teoritis, merumuskan hipotesis. Kedua, tahap penelitian mengidentifikasi populasi yang diteliti, mengkhususkan metode untuk mengukur variabel penelitian,merancang rencana sampling, mengakhiri dan meninjau rencana penelitian, melaksanakan pilot penelitian dan membuat revisi. Ketiga, mendesain instrumen pengumpulan data penelitian dan model peningkatan kinerja karyawan dalam rangka meningkatkan kinerja karyawan secara berkelanjutan, keempat, tahap empirik dimana pada tahap ini dilakukan pengumpulan data dan penyiapan data untuk dianalisis dan kelima tahap analitik yang memuat kegiatan analisis data dan interpretasi hasil serta pengujian terhadap hipotesis yang telah disusun. 
Adapun yang akan menjadi populasi dalam penelitian ini adalah seluruh karyawan PT Mawar Sebelas Jl. Mawar No. 11 Drangong Taktakan Serang-Banten sebanyak 55 karyawan. Dalam penelitian ini sampel yang digunakan oleh penulis adalah berdasarkan metode sampling jenuh.

\section{Hasil dan Pembahasan}

\section{1) Uji Validitas dan Uji Reabilitas}

Berdasarkan hasil uji validitas memperlihatkan bahwa nilai-nilai koefisien atau rhitung untuk setiap variabel lebih besar dari nilai rtabel, dengan demikian dapat dikatakan bahwa seluruh instrument dalam penelitian ini bernilai valid. Hasil uji validitas instrument penelitian seperti gambar 1.

Tabel 1.1. Uji Validitas

\begin{tabular}{|r|l|l|l|l|l|l|l|l|l|l|l|l|l|}
\hline Rtabel & 0,2732 & 0,2732 & 0,2732 & 0,2732 & 0,273 & 0,2732 & 0,273512 & 0,2732 & 0,2732 & 0,2732 & 0,2732 & 0,2732 & 0,2732 \\
\hline RW & 0,579 & 0,651 & 0,425 & 0,688 & 0,561 & 0,560 & 0,643 & 0,570 & 0,418 & & & & \\
\hline PS & 0,527 & 0,673 & 0,611 & 0,667 & 0,495 & 0,617 & 0,533 & 0,434 & 0,516 & & & & \\
\hline KO & 0,275 & 0,454 & 0,499 & 0,663 & 0,493 & 0,610 & 0,710 & 0,662 & 0,660 & 0,592 & 0,319 & 0,290 & 0,319 \\
\hline KK & 0,712 & 0,746 & 0,686 & 0,806 & 0,717 & 0,654 & 0,838 & 0,714 & & & & & \\
\hline
\end{tabular}

Sumber: Hasil Pengolahan Data spss v.24

Uji reliabilitas dilakukan dengan menghitung koefisien alpha cronbach untuk tingkat kosisten variabel X1 sebesar 0,731 dan variabel X2 didapat nilai alpha cronbach sebesar 0,733dan variabel X3 diperoleh nilai alpha cronbach sebesar 0,751 dan variabel $\mathrm{Y}$ diperoleh nilai alpha cronbach sebesar 0,859 , hal ini berarti alpha yang diperoleh dari variabel adalah $>$ rtabel dan itu artinya bahwa seluruh pertanyataan yang terdapat pada kuisioner dapat dinyatakan relibel.

\section{Analisis Deskriptif}

\section{Reward (X1)}

Berdasarkan tanggapan responden pada prinsipnya reward termasuk kategori BAIK, karena rata-rata skor 205,3. Adapun yang perlu dipertahankan oleh managerial yaitu beberapa orang memiliki kebutuhan untuk menyelesaikan pekerjaannya dan mereka akan merasa puas setelah tugas atau pekerjaan tersebut terselesaikan dengan baik.

\section{Punishment (X2)}

Deskriptif berdasarkan tanggapan pada prinsipnya punishmenttermasukkategori BAIK, karena rata-rata skor 209,2. Adapun yang perlu dipertahankan oleh managerial yaitu karyawan selalu menjauhi larangan yang berisiko. Tata tertib kerja diberlakukan bagi karyawan, agar dapat melaksanakan fungi/tugas/jabatan secara optimal dan terciptanya suasana kerja yang aman, tertib dan teratur pada PT Mawar SebelasSerang.

\section{Keadilan organisasi (X3)}

Berdasarkantanggapan responden padaprinsipnya Keadilan Organisasi termasuk katagori BAIK, karena rata-rata skor 214,76. Adapun yang perlu dipertahankan oleh managerial yaitu pimpinan selalu mengklarifikasi keputusan dan memberikan informasi ketika diminta oleh karyawan, dalam hal ini pemimpin dapat dikatakan adil oleh karyawan apabila dalam pengambilan keputusan karyawan diberikan kesempatan untuk menyuarakan pendapat dan pandangan mereka.

\section{Kinerja (Y)}

Deskriptif berdasarkan tanggapan responden pada prinsipnya Kinerja karyawan termasuk dalam katagori BAIK, karena rata-rata skor 206,75. Adapun yang perlu dipertahankan oleh managerial yaitu karyawan dapat menyelesaikan target yang diminta oleh perusahaan dengan hasil yang baik. Dalam hal ini kinerja karyawan yang dihasilkan baik kualitas dan kuantitas hasil kerja dan dapat dipertanggungjawabkan 
sesuai dengan perannya didalam perusahaan sesuai dengan kemampuan, keterampilan dalam penyelesaiantugas.

8. Berdasarkan dari hasil pengolahan Uji SPSS 24.0 memperlihatkan bahwa:

1. Apakah reward berpengaruh terhadap kinerjakaryawan

Bahwa koefisien korelasi bernilai sebesar 0,465 berada pada katagori sedang 0,40-0,599 dan mempunyai tingkat hubungan yang sedang namun positif. Setelah pengujian parsial menunjukkan hipotesis dapat diterima karena thitung>ttabel, dengan demikian hipotesis reward terdapat pengaruh positif dan signifikan pada PT Mawar Sebelasserang.

2. Apakah punishment berpengaruh terhadap kinerjakaryawan

Bahwa koefisien korelasi Punishment bernilai sebesar 0,402 berada pada kategori sedang 0,40-0,599 dan mempunyai tingkat hubungan yang kuat, sedangkan berdasarkan asosiatif sebesar 0,176 bernilai positif. Setelah pengujian parsial dilakukan hipotesis dapat diterima jika thitung>ttabel, dengan demikian hipotesis punishment terdapat pengaruh posisitf dan signifikan pada PT Mawar Sebelasserang.

3. Apakah keadilan organisasi berpengaruh terhadapkinerja

Bahwa koefisien korelasi Keadilan Organisasi bernilai sebesar 0,390 berada pada kategori rendah 0,200,399 dan mempunyai tingkat hubungan yang rendah sedangkan berdasarkan asosiatifsebesar 0,312bernilai positif. Setelah pengujian parsial dilakukan hipotesis dapat diterima jika thitung >ttabel, dengan demikian hipotesis keadilan organisasi terdapat pengaruh positif dan signifikan pada PT Mawar Sebelasserang.

4. Apakah pengaruh reward, punishment dan keadilan organisasi terhadap kinerja karyawan

Berdasarkan asosiatif menunjukkan reward, punishment dan keadilan organisasi secara simultan sebesar35,5\% dan $74,5 \%$ sisanya dipengaruhi oleh faktor lain maka hipotesis dapat diterima karena fhitung> ftabel. Diperoleh untuk reward sebesar 0,465, punishment sebesar 0,402 dan keadilan organisasi sebesar 0,390 pada PT Mawar Sebelasserang.

\section{SIMPULAN DAN SARAN}

\section{Simpulan}

Berdasarkan hasil analisis dan pembahasan, tentang Reward, Punishmet dan Keadilan Organisasi terhadap Kinerja Karyawan pada PT MAWAR SEBELAS SERANG, Penulis menarik kesimpulan sebagai berikut :

1. Reward berpengaruh positif dan signifikan secara parsial terhadap kinerja karyawanpada

2. Punishment berpengaruh positif dan signifikan secara parsial terhadap kinerja karyawanpada

3. Keadilan Organisasi berpengaruh positif dan signifikan secara parsial terhadap kinerja karyawan.

4. Reward, punishment dan Keadilan Organisasi berpengaruh positif dan signifikan sebesar 35,5\% secarasimultan.

\section{SARAN}

Berdasarkan dari hasil kesimpulan di atas, maka penulis dapat memberikan saran sebagai berikut :

1. Reward termasuk katagori baik yang perlu dipertahankan oleh managerial penyelesaian tugas pekerjaan dan tingkat kepuasan pegawai supaya menimbulkan motivasi positif pada karyawan.

2. Punishment termasuk katagori baik, yang perlu dipertahankan oleh managerial yaitu karyawan selalu menjauhi resiko pekerjaan dengan melalui kejelasan tata tertib kerja dan menciptakan suasana kerja yang aman dan nyaman.

3. Keadilan Organisasi termasuk katagori baik,yang perlu dipertahankan oleh managerial yaitu pimpinan selalu mengklarifikasi keputusan dan memberikan informasi etika pada karyawan.

4. Kinerja karyawan termasuk katagori baik, yang perlu dipertahankan oleh managerial yaitu karyawan dapat menyelesaikan target dan dengan hasil kualitas yang baik 


\section{DAFTAR PUSTAKA}

Gibson, J. L., Donnelly, J. H., Ivancevich, J. M., \& Konopaske, R. (2012). Organizations: Behavior, structure, processes. Singapore: McGraw-Hill.

Hasibuan, Malayu S.P. (2002). Manajemen Sumber Daya Manusia, Edisi Revisi.Jakarta: PT. Bumi Aksara

Ivancevich, Konopaske Dan Matteson. 2007. Perilaku Manajemen Dan Organisasi. alih bahasa Gina Gania. Jakarta : Erlangga.

Ivancevich, Konopaske dan Matteso, Perilaku Manajemen Dan Organisasi: alih bahasa Gina Gania, Jakarta : Erlangga, 2007, h. 224

Mangkunegara P anwar (2013) manajemen sumber daya perusahaan cetakan kesebelas. Bandung :PT remaja rosdakarya

Niehoff, B. P., \& Moorman, R. H. 1993. Justice as a mediator between methods of monitoring and organizational citizenship behavior. The Academy of Management Journal, 36, 527-556.

Purwanto,M. ngalim. 2006. Ilmu pendidikan teoritis dan praktis. Bandung: Remaja Rosdakarya

Veithzal Riva'i, Manjamen Sumber Daya Manusia untuk Perusahaan dari Teori ke Praktik (Jakarta: Radja Grafindo Persada, 2004), 269 